\title{
PROTOTYPE MONITOR FOR AIRBORNE IODINE AND FISSION PRODUCTS
}

J.W. Adams
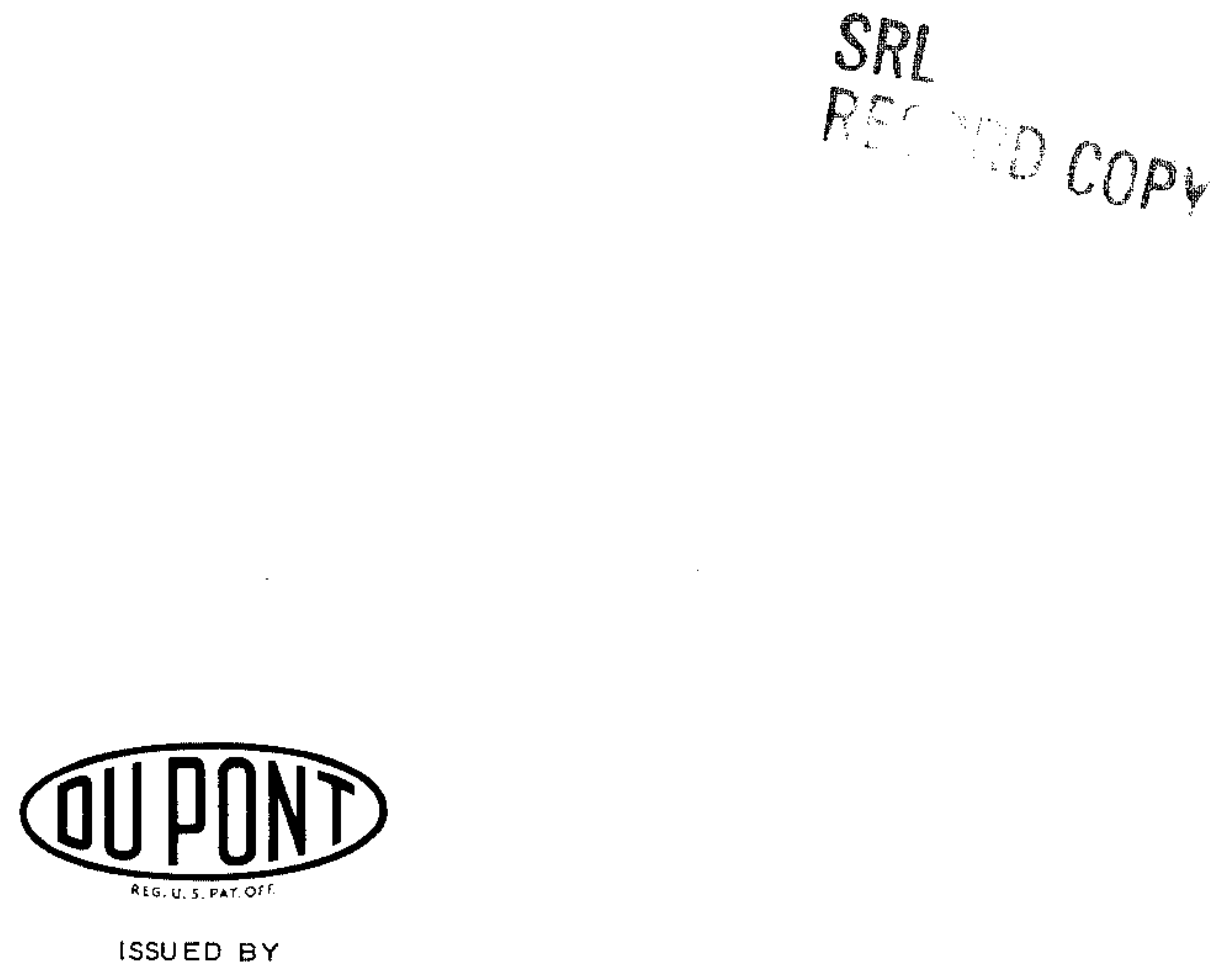

Savannah River Laboratory

Aiken, South Carolina 


\section{LEG A L NOTICE}

This repart was prepared as an account of Government sponsored work. Neither the United States, nor the Commission, nor any person acting on behalf of the Commission:

A. Makes any warranty or representation, expressed or implied, with respect to the accuracy, completeness, or usefuiness of the information contained in this report, or that the use of any information, apparatus, method, or process disclosed in this report may not infringe privately owned rights; or

B. Assumes any liabilities with respect to the use of, or for damages resulting from the use of any information, apparatus, method, or process disclosed in this report.

As used in the above, "person acting on behalf of the Commission" includes any employee or contractor of the Commission, or employee of such contractor, to the extent that such employee or contractor of the Commission, or employee of such contractor prepares, disseminates, or provides access to, any information pursuant to his employment or contract with the Commission, or his employment with such contractor.

Printed in USA. Price $\$ 0.50$

Available from the Clearinghouse for Federal Scientific

and Technical Information, National Bureau of Standards,

U. S. Department of Commerce, Springfield, Virginia 


\title{
664514 \\ DP-908 \\ Ins truments \\ (TID-4500, 33rd Ed.)
}

\section{PROTOTYPE MONITOR FOR AIRBORNE IODINE} AND FISSION PRODUCTS

\author{
by \\ Joseph W. Adams* \\ Approved by \\ T. C. Evans, Superintendent \\ Engineering Assistance Section \\ Works Technical Department \\ Savannah River Plant \\ July 1964
}

E. 1. DU PONT DE NEMOURS \& COMPANY SAVANNAH RIVER LABORATORY

AIKEN, SOUTH CAROLINA

CONTRACT AT(07-2)-1 WITH THE

UNITED STATES ATOMIC ENERGY COMMISSION

* Present Address: Engineer1ng Department

E. I. du Pont de Nemours and Company

Wilmington, Delaware 


\begin{abstract}
The design is presented for a new system for monitoring gases from the dissolution of irradiated uranium in radiochemical separations processes at the Savannah Rlver Plant. The system includes f1Iter paper and activated charcoal to trap particulate activity and lodine vapor; as activity builds up, it is detected by a concentrically mounted GM tube. Early operating experience is also discussed.
\end{abstract}




\section{PROTOTYPE MONITOR FOR AIRBORNE IODINE AND FISSION PRODUCTS}

Gases from the dissolution of irradiated uranium in radiochemical separations processes at the Savannah River Plant contain small amounts of radioactive lodine, fission products, and noble gases. Careful monitoring of the gases is necessary for protection against abnormal releases of $I_{2}$ and fission products (principally $\mathrm{Ru}$ ) to the environment.

$I^{231}$, present in dissolver gases as a vapor, causes the greatest concern because it can disperse over a wide area and become a health hazard. The fission products in the gases are attached to particles, which can also be dispersed as they leave the stack. An instrument to monitor dissolver gases must distinguish between radioactivity from iodine and fission products and from that of noble gases.

\section{Background}

A caustic scrubber and a single channel pulse height analyzer were formerly used to collect and measure the activity in dissolver-gas samples. Samples of gas were bubbled through an aqueous solution of $\mathrm{NaOH}$ to remove lodine and other fission products; the caustic solution was then passed by a sodium lodide (TI) crystal and counted. A single channel pulse helght analyzer was set to detect the $0.36 \mathrm{Mev}$ peak for $I^{131}$.

Operation of this equipment was not satisfactory. Accurate measurements were difficult because spurious counts were introduced into the $0.36-\mathrm{Mev}$ region by scatter from higher energy disintegrations. The average indicated error, from this and other sources, compared to laboratory counting, was $+158 \%$. The error ranged from $-46 \%$ to $+2430 \%$.

Maintenance required by the scrubber system and analyzer was excessive. The agitator, mechanical components, pumps, and valves leaked and required frequent repair. The electronic equipment was corroded by chemlcal vapors which (along with other troubles) rendered it inoperative for as many as 6 days per month. In addition, a calibration routine had to be performed each day to ensure proper operation of the monitor. 
New Monitor

A new monitoring system (Figure 1) was designed with a filter paper and an activated charcoal canister. Gas passes through the monitor at a rate of $5 \mathrm{cfm}$, and the activity is trapped on the combination filter-adsorber (Figures 1 and 2). Particulate activity (primarily $\mathrm{Ru}^{108}$ ) is trapped on the filter paper and gaseous activity (primarily I I3I) is trapped on the activated charcoal. As activity bullds up, it is detected by the concentrically mounted GM tube; the amount detected is indicated on a log count rate meter and recorder. When the activity goes above a preset point, an alarm is sounded. If identification of individual isotopes is required, the filter assembly may be readily removed for counting with a scintillation probe and multichannel pulse helght analyzer.

The four principal sources of error are:

- Sampling errors, which were also a problem w1th the old system, are due to nonuniform sampling and line losses. These errors vary with process conditions, but are generally less than $\pm 15 \%$ for $I^{131}$.

- Variations in instrument filter and adsorber efficlency cause an error of less than $\pm 15 \%$.

- Instrument accuracy is about $\pm 20 \%$.

- Noble gas background is a problem for only a short time after a new filter is installed. At the point of sampling, xenon and krypton activity in a gas sample w1II be five to twenty times that of other fission products.

Accumulation of these errors could lead to a result which is in error by 50\%. This exror is not excessive for an instrument of this kind that covers five decades.

Figure 2 is a cross-sectional view of the prototype detector cell. Sample gas flows in at the top left, through the filter, and out at the lower right. Activity is captured on the filter paper or on the surface of the charcoal. The GM tube in the center of the assembly measures the activity. A thin shield is placed around the GM tube to prevent it from becoming contaminated in event of a filter breakthrough. Stainless steel construction is used throughout the cell to prevent corrosion. Lead shielding is placed around the detector to reduce the background count. 


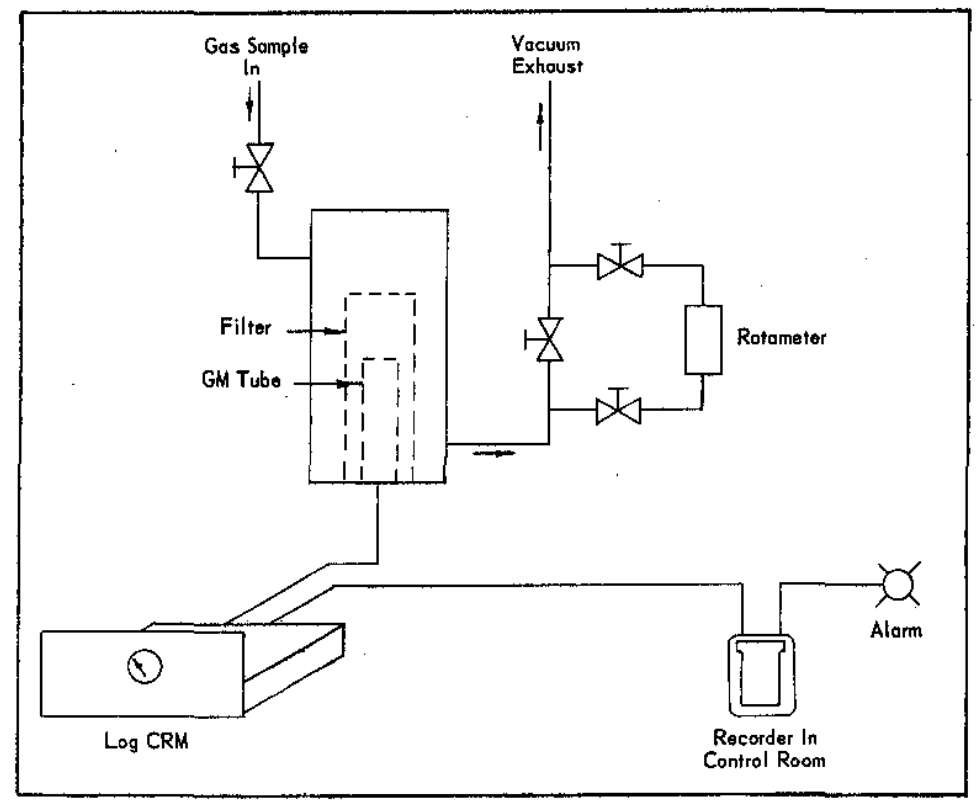

FIG. 1 SCHEMATIC OF SIMPLIFIED MONITOR

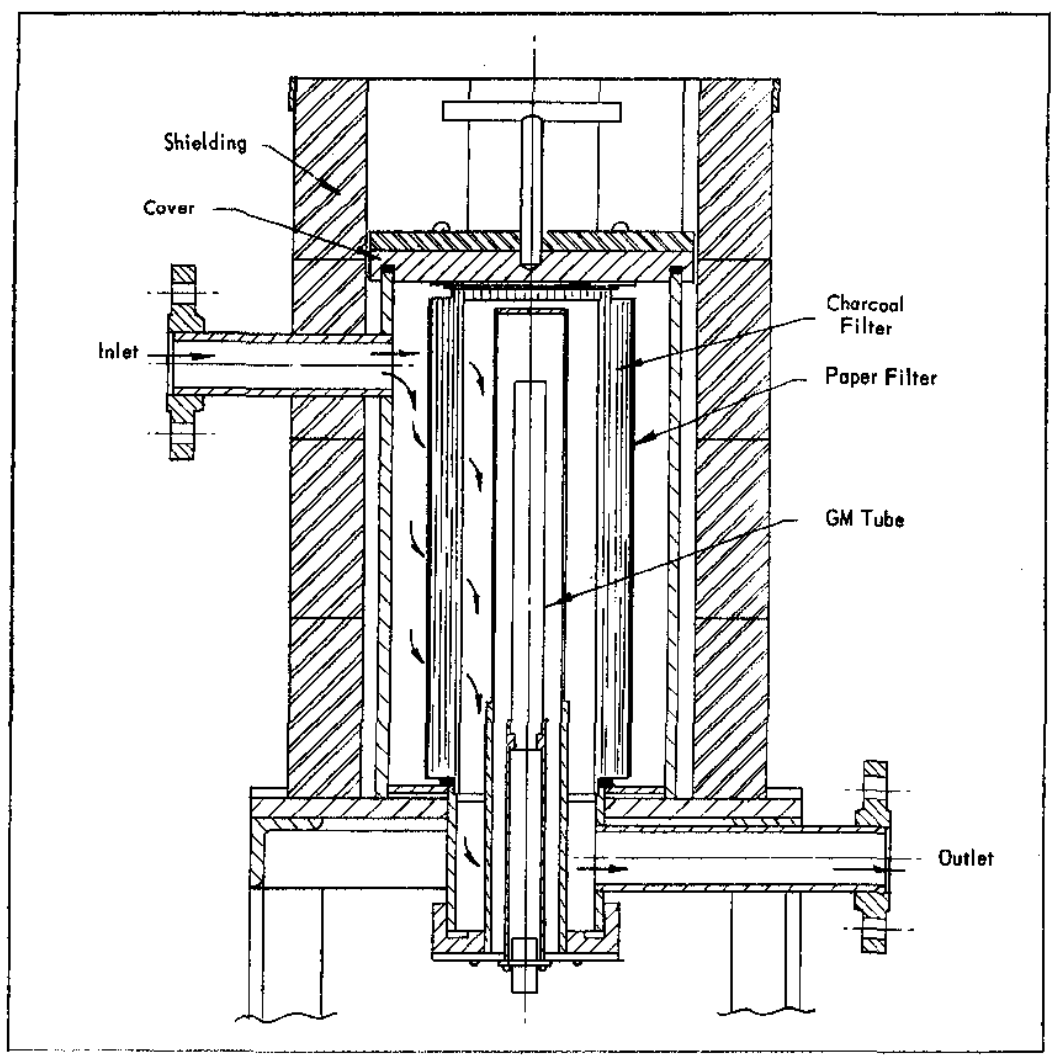

FIG. 2 CROSS SECTION OF DETECTOR CELL 
HV 70 filter paper is used in the monitor.' Tests(1) at other sites and at the Savannah River Plant (SRP) have shown that this filter paper has an efficiency greater than $99 \%$ for particles larger than $0.3 \mathrm{micron}$. Dorex type $\mathrm{H}-42$ charcoal canisters have been tested $(2)$ and found to be $99.99 \%$ efficient in the collection of lodine. However, collection of lodine at SRP has not exceeded an efflclency of $85-90 \%$. This difference in efflciency has not been fully explained, but it is belleved to result from the reaction of lodine with other stack-gas constituents to form compounds which are not trapped as efficientiy as 1odine 1tself. An efficlency of $85 \%$ is more than adequate for this usage.

A logarithmic count rate meter over the range of 10 to $10^{6} \mathrm{cpm}$ ( $30 \mathrm{mill1}$ curies to 200 curles) is used with a transistor version of the Cooke-Yarborough clrcuit(3). Figure 3 is a schematic diagram of the circuit.

\section{Operating Experience}

In May 1962, an 1mproved prototype monitor was installed in the field to count gross activity in gas samples. Since installation no maintenance, other than weekly replacement of the filter assembly, was required. Analysis of the canister and filter paper on a multichannel pulse height analyzer revealed good separation (Figure 4) of particulate and gaseous fission products. As a result of the good separation with charcoal and paper filters, the two filters were physically separated in later field installations. Passage of dissolver gas samples through filter paper and charcoal in serles makes it possible to count each separately.

\section{REFERENCES}

1. Media for Air Cleaning and Alr-Assay Purposes. Summary Report to Division of Engineering, Arthur D. Little, Inc., Cambridge, Massachusetts, USAEC Report AECU-3119 (1955).

2. "Removal of Radioactive Iodine". Nuclear Safety $I(3)$, 44 (March 1960).

3. E. H. Cooke-Yarborough and E. W. Pulsford. "An Accurate Logarithmic Counting-Rate Meter Covering a W1de Range". Proceedings I.E.E. 98, Part II, 196-203 (1951). 


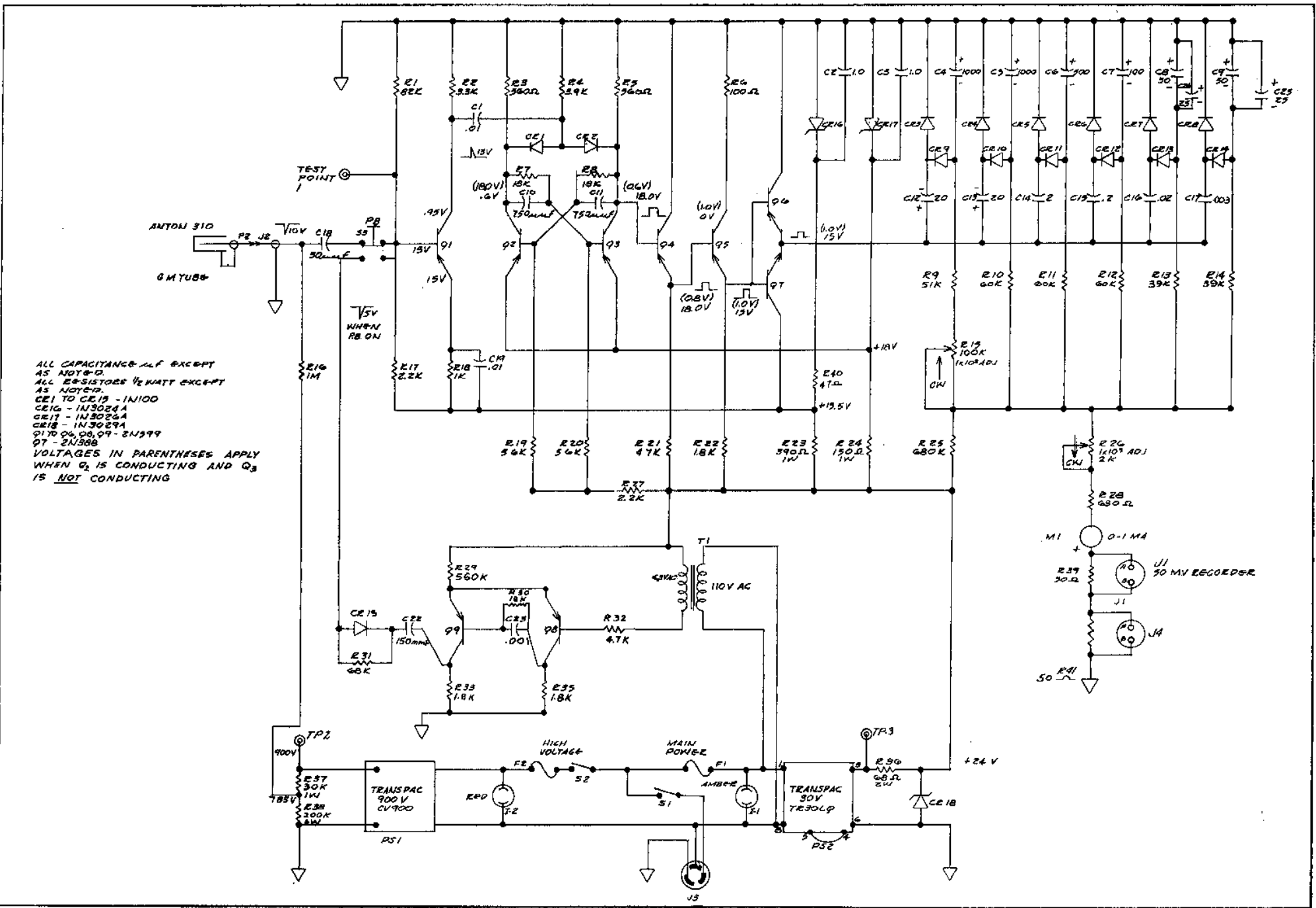

FIG. 3 SCHEMATIC OF LOGARITHMIC COUNT RATE METER 


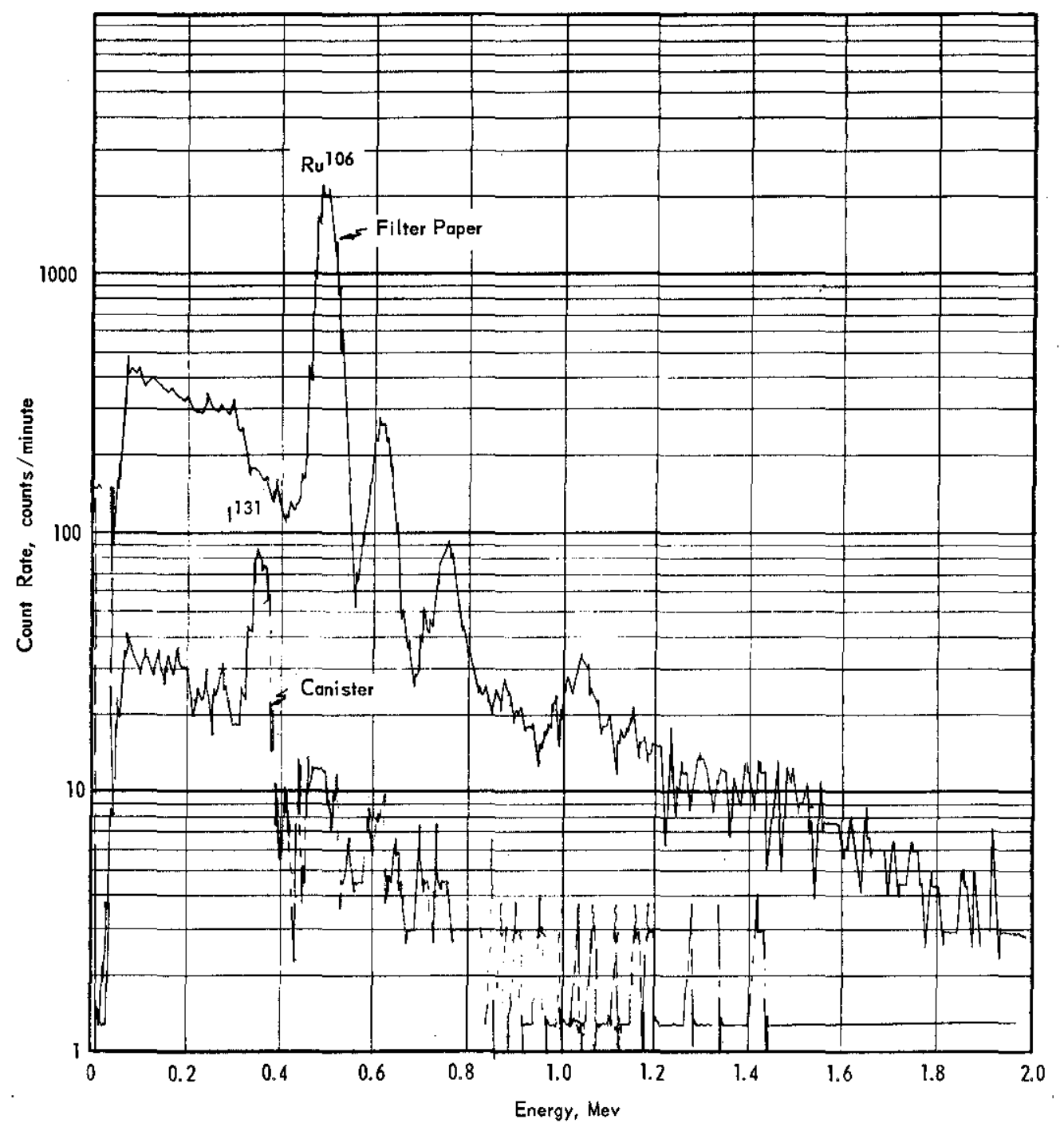

FIG. 4 SCAN OF FILTER ASSEMBLY MADE WITH PULSE HEIGHT ANALYZER 